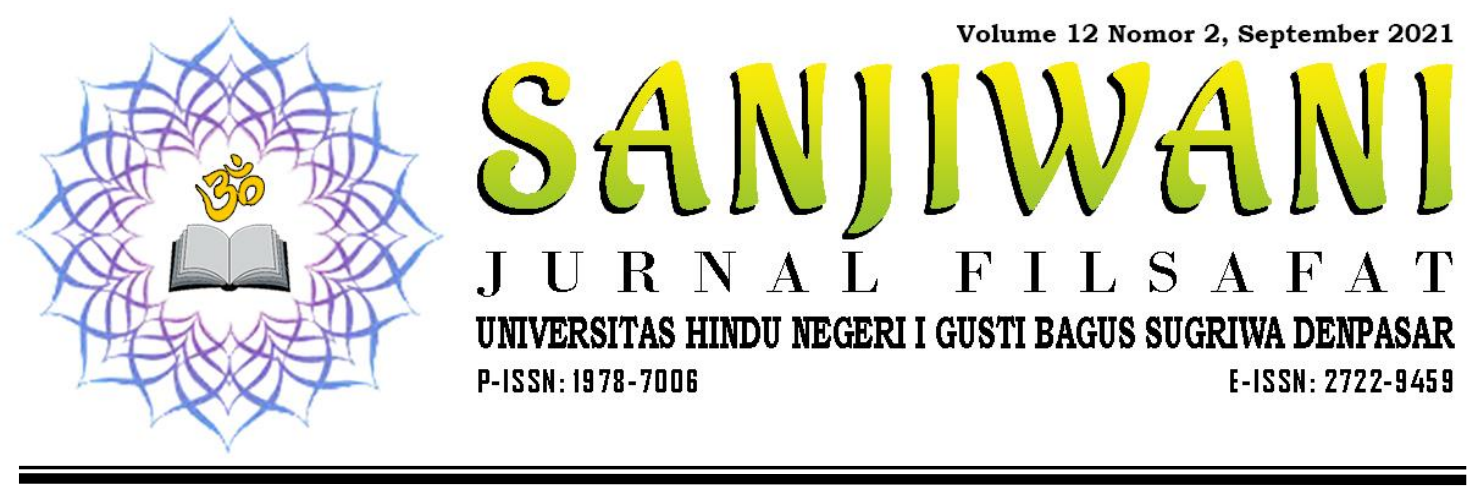

\title{
Argumen Logis tentang Eksistensi Tuhan dalam Wacana Filsafat Ketuhanan
}

\author{
Gede Agus Siswadi \\ Universitas Hindu Negeri I Gusti Bagus Sugriwa Denpasar \\ gedeagussiswadi@gmail.com
}

\begin{tabular}{|ll|}
\hline Keywords: & ABSTRACT \\
\hline $\begin{array}{l}\text { God's Existence; } \\
\text { Philosophy of }\end{array}$ & Talking about God will have no end, because after all, humans \\
God; Logical & cannot be separated from the various weaknesses inherent in \\
Argument & humans. An interesting question from the philosophy of divinity is \\
& whether God really exists or is it merely an illusion or human \\
projection. This article seeks to explore and record evidence related & \\
& to the existence of God. The results of this paper are (1) ontological \\
& arguments that show God exists based on the definition of God, (2) \\
& cosmological arguments which explain that the creation of this \\
& universe and the very regular motion of nature, (3) design \\
& arguments, which are based on God is a smart designer (4) moral \\
& argument is explained that God is the result of thought, namely \\
that there is no sense in having a moral command, otherwise God & governs the moral command, (5) teleological argument based on the \\
purpose of goodness.
\end{tabular}

\begin{tabular}{|c|c|}
\hline Kata Kunci & ABSTRAK \\
\hline Eksistensi & Membicarakan tentang Tuhan memang tidak akan \\
\hline Tuhan; Filsafat & menemui akhir, karena sesungguhnya bagaimanapun juga \\
\hline Ket & manusia mempunyai kecenderungan untuk mengakui \\
\hline Argumen Logis & an ini, tidak lepas dari \\
\hline & ang melekat pada dirı manusia. \\
\hline & Pertanyaan menarik dari filsafat ketuhanan adalah apakah \\
\hline & $\begin{array}{l}\text { Tuhan memang ada atau hanya sekadar ilusi atau proyeksi } \\
\text { manusia. Artikel ini berupaya untuk menelusuri serta } \\
\text { mencatat bukti-bukti terkait dengan adanya Tuhan. Hasil } \\
\text { dari tulisan ini adalah (1) argumen ontologis yang }\end{array}$ \\
\hline
\end{tabular}


menunjukkan Tuhan ada berdasarkan definisi tentang Tuhan, (2) argumen kosmologis yang menjelaskan bahwa penciptaan alam semesta ini serta gerak alam yang sangat teratur, (3) argumen desain, didasarkan pada Tuhan adalah pendesain yang cerdas, (4) argumen moral dijelaskan bahwa Tuhan merupakan hasil pemikiran yaitu tidak masuk akal adanya perintah moral, kalau tidak Tuhan yang mengatur perintah moral tersebut, (5) argumen teleologis yang didasarkan pada tujuan kebaikan.

\section{PENDAHULUAN}

Manusia sudah lama menyembah Tuhan dalam berbagai bentuk dan filsafat dimanapun tertarik untuk memikirkan tentang Tuhan dari berbagai sudut. Dan dalam abad ke-20 filsafat ketuhanan sendiri seakan-akan menghilang dari wacana filsafat. Filsafat abad ke-20 memikirkan manusia dan pengetahuannya, bahasa manusia, masyarakat dan budaya, tetapi tidak banyak memikirkan tentang Tuhan, atau sekurang-kurangnya Tuhan tidak lagi menjadi objek utama diskursus filsafat (Magnis Suseno, 2006: 19).

Pada mulanya manusia mengakui hanya ada satu Tuhan tertinggi, yang telah menciptakan dunia dan menata urusan manusia dari kejauhan. Kepercayaan terhadap satu Tuhan tertinggi (kadang-kadang disebut Tuhan langit, karena dia diasosiasikan dengan ketinggian) masih terlihat dalam agama suku-suku pribumi Afrika, mereka mengungkapkan kerinduan terhadap Tuhan melalui doa (Armstrong, 2021: 27).

Memahami Tuhan atau yang transenden secara rasional tak lain adalah upaya manusia untuk memahami hakikat yang kasat mata dan yang gaib serta punya tujuan memantapkan keyakinannya akan keberadaan yang transenden yang dianggap mempengaruhi seluk-beluk kehidupan ini. Dalam waktu yang sama, orang yang mengaku tidak percaya kepada yang transenden juga punya keinginan untuk meniadakan secara rasional yang transenden itu, baik dengan maksud menolaknya ataupun karena tidak mampu menangkap eksistensinya. Pada titik ini dapat dikatakan, apapun tujuan untuk memahami dan menolak yang transenden menjadi bukti bahwa yang transenden betul-betul telah memengaruhi kehidupan manusia.

Penelusuran tentang hakekat Tuhan dalam sejarah pemikiran manusia memang senantiasa menarik untuk dikaji. Berbagai spekulasi dan bukti-bukti tentang keberadaan Tuhan secara variatif telah banyak ditengahkan oleh para cendekiawan dalam setiap masa. Problematika tentang Tuhan merupakan problem universal yang selalu ada dalam sejarah manusia, sehingga problem tentang Tuhan berada pada tingkatan pertama spekulasi filosofis.

Para pencari Tuhan selalu memiliki persepsi yang berbeda tentang Tuhan sejak dahulu kala hingga saat ini. Gagasan manusia tentang Tuhan memiliki sejarah, karena gagasan itu selalu mempunyai arti yang berbeda bagi setiap kelompok manusia yang menggunakannya di berbagai periode waktu. Gagasan tentang Tuhan yang dibentuk oleh sekelompok manusia pada satu generasi bisa saja menjadi tidak bermakna bagi generasi lainnya (Mustofa, 2008: 255). 
Sebuah kajian metafisika yang membicarakan tentang Tuhan memiliki kekhususan dibandingkan dengan objek metafisika lainnya. Apabila manifestasi lahiriah dari semesta maupun jiwa dapat ditangkap indera, maka hal yang sama tidak berlaku bagi realitas ketuhanan. Tuhan adalah suatu yang mutlak tidak dapat ditangkap indera. Metafisika yang mengkaji tentang Tuhan disebut filsafat ketuhanan (teologi naturalis) untuk membedakannya dari teologi adikodrati atau teologi wahyu. Apabila filsafat ketuhanan mengambil Tuhan sebagai titik akhir atau kesimpulan seluruh pengkajiannya, maka teologi wahyu memandang Tuhan sebagai titik awal pembahasannya.

Filsafat ketuhanan berurusan dengan pembuktian kebenaran adanya Tuhan yang didasarkan pada penalaran manusia. Filsafat ketuhanan (teologi naturalis) tidak mempersoalkan eksistensi Tuhan, disiplin tersebut hanya ingin menggaris bawahi bahwa apabila tidak ada penyebab pertama yang tidak disebabkan maka kedudukan benda-benda yang relatif kontingen tidak dapat dipahami akal.

Kepercayaan kepada Tuhan telah dipastikan sama sekali tidak bertentangan dengan eksistensi manusia, karena dalam diri manusia terdapat pengalaman-pengalaman yang sifatnya religius dan misterius serta memiliki halhal yang transenden di dunia. Banyak filsuf maupun teolog yang menghadirkan dan mengemukakan beberapa macam bukti-bukti yang bersifat rasional dan masuk akal. Bukti-bukti tersebut biasanya para filsuf menyebutkan dengan eksistensi karena bertujuan untuk menjawab pertanyaan tentang akal budi sehingga bukti-bukti eksistensi tersebut hanya sebagai kebutuhan manusia untuk mendeskripsikan keberadaan Tuhan.

Membuktikan keberadaan Tuhan berarti harus menyusun argumen rasional untuk memberikan kepastian terhadap keberadaan Tuhan. Para filsuf dan teolog tidak pernah tercapai tetapi mereka mengemukakan pikiran-pikiran yang merujuk ke arah Tuhan, akan tetapi bukti tersebut bukan sebagai bukti dalam arti yang sesungguhnya. Oleh karenanya dalam hal ini tidak terdapat bukti-bukti yang sungguh melainkan pandangan terhadap Tuhan. Menurut Huijbers (1995: 137) dominasi bukti tentang adanya Tuhan dipersepsikan tergantung dari situasi pribadi tiap orang, tetapi tidak hanya bukti rasional saja yang dapat dijadikan pedoman, melainkan mempunyai keyakinan terhadap adanya Tuhan, dengan demikian ia tidak diyakinkan oleh ide-ide rasional dan Tuhan dapat dibuktikan lewat pengalaman-pengalaman religius.

Dalam berbagai diskursus dikatakan bahwa Tuhan sebagai penggerak pertama yang berarti Tuhan sebagai sebab pembuat (sebab, dalam kedudukannya sebagai pembuat), akan tetapi seorang filsuf Aristoteles mengatakan bahwa Tuhan sebagai zat penggerak yang diam (tidak bergerak), dan gerakan segala sesuatu yang ada dalam alam ini menuju kepadanya, yang berarti bahwa Tuhan hanya menjadi tujuan semata. Pengaruhnya pada alam ini tidak lebih daripada pengaruh patung yang indah pada jiwa orang yang mengaguminya.

Oleh karenanya konsepsi serta hakekat tentang Tuhan telah menjadi perenungan selama ini. Sejak Yunani kuno hingga sekarang ini. Awal mula dari filsafat Yunani, Tuhan selalu dipahami sebagai asal-usul kejadian semua yang 
ada ini. Oleh karena itu, bukti tentang adanya Tuhan secara tidak langsung akan bersentuhan dengan agama. Bahkan setiap agama memiliki konsepsi tentang Tuhan. Bukti tentang eksistensi Tuhan banyak dikaji oleh para filsuf maupun teolog sejak zaman sebelum masehi. Timbulnya tuntunan-tuntunan yang menghendaki bahan bukti bagi adanya Tuhan, disebabkan pernyataan adanya Tuhan tidak jelas. Kiranya ada alasan-alasan untuk percaya bahwa Tuhan tidak bereksistensi atau lebih tepat Tuhan tidak ada. Namun demikian, orang tetap merasa sangat gembira bila ada yang mengatakan bahwa seeorang telah membuktikan secara pasti Tuhan itu ada, khususnya bila orang yang mengatakan tadi adalah seorang ilmuan atau yang mendasari buktinya pada ilmu pengetahuan. Disinilah teka-teaki masalahnya. Dengan demikian tulisan ini berupaya untuk menjelaskan beberapa bukti tentang eksistensi Tuhan.

\section{PEMBAHASAN}

Anselmus mendefinisikan Tuhan sebagai "tidak ada yang lebih besar daripada-Nya untuk dapat direnungkan". Filsuf panteis Baruch Spinoza membawa gagasan tersebut lebih ektrem: "Melalui Tuhan aku memahami sesuatu mutlak tak terbatas, yaitu, suatu zat yang mengandung atribut-atribut tak terbatas, masing-masing menyiratkan esensi yang kekal dan tidak terbatas". Bagi Spinoza, seluruh alam semesta terbuat dari satu zat, yaitu Tuhan, atau padanannya yaitu alam (Wibowo, 2006: 17). Dalam konteks ini argumen tentang eksistensi Tuhan akan dijelaskan dalam bentuk argumen ontologis, argumen kosmologi, argumen desain, argumen moral dan argumen teleologis.

\subsection{Argumen Ontologis tentang Eksistensi Tuhan}

Argumen ontologis tentang keberadaan Tuhan pertama kali dipelopori oleh seorang filsfuf yang bernama Plato pada tahun 428-343 SM dengan teori alam sebagai gagasannya. Alam semesta ini merupakan peniruan dari alam ide. Alam ide berada di luar alam nyata dan ide-ide itu kekal. Benda-benda yang tampak di alam nyata senantiasa berubah, bukanlah sebuah hakekat tetapi hanya bayangan. Yang mutlak baik (the absolute good) itu adalah sumber, tujuan dan sebab dari segala yang ada, yang mutlak baik itulah disebut sebagai Tuhan (Bahrum, 2013: 36).

Karya Plato yang berjudul Cratylus menjelaskan bahwa Tuhan tidak dapat dikenal dan tidak ada esensinya yang dapat dikenali. Nama-nama yang digunakan untuk menunjukkan sifat-sifat Tuhan tidak berarti manusia telah sungguh-sungguh mengenalnya. Nama-nama itu sesungguhnya menjelaskan sifat atau esensi Tuhan, tetapi hanya pendapat yang lemah dari manusia tentang Tuhan. Nama-nama itu hanya bertujuan sebagai konsep yang dibuat manusia tentang ketuhanan. Tidak ada nama-nama atau konsep yang universal tentang ketuhanan. Sekalipun dalam hal ini Plato menentang naturalisme dan antrofomorfisme terhadap ketuhanan, tetapi Plato mengesampingkan konsep ketuhanan dalam filsafatnya (Apau, 1989: 29-31).

Ketuhanan menurut Plato bukanlah pencipta yang eksternal yang supernatural dan penciptaan menurut Plato bukanlah dari ketiadaan mutlak atau ex nihilio, melainkan dalam kerangka emanasi dan partisipasi dari apa yang 
disebut sebagai ide dari segala ide atau intelegensi tertinggi di alam semesta dan berupa hukum-hukum yang memberikan ketertiban dan keteraturan dalam segala makhluk serta benda dalam alam semesta ini. Itu sebabnya benda-benda langit dalam konsep ketuhanan Plato disebut pula Tuhan karena di dalamnya mengandung "jiwa alam semseta", namun benda-benda langit itu sekalipun disebut Tuhan tidak dijadikan sebagai objek penyembahan (Weisman, 2005: 17).

Selanjutnya seorang filsuf yang bernama Anselmus dalam usahanya untuk membuktikan eksistensi Tuhan berawal dari pemahamannya tentang Tuhan. Menurut Anselmus Tuhan adalah "yang tentangnya tidak dapat dipikirkan kembali sesuatu yang lebih besar (deus est id quod mius cogitari nequit)". Definisi ini berangkat dari pemikiran Anselmus sendiri, ia menemukan bahwa dalam intelek tidak ada sesuatu yang lebih besar yang dapat dipikirkan, sesuatu itulah yang disebutnya Tuhan. Oleh karena itu, dalam pencariannya ini akhirnya ia mengerti bahwa untuk mengetahui sesuatu tentang Tuhan, ia membutuhkan suatu penerangan ilahi. Dalam proslogion ia mengungkapkan: "jadikanlah aku melihat cahaya-Mu, singkapkanlah dirimu ketika aku menemukan-Mu, sebab saya tidak bisa menemukan, kecuali engkau mengajarkan, kecuali engkau menyingkap diri-Mu" (Maskhuroh, 2017: 575).

\subsection{Argumen Kosmologi tentang Eksistensi Tuhan}

Plato merupakan seorang filsuf yang pertama kali mencetuskan argumen kosmologis tentang keberadaan Tuhan. Pembuktian tentang adanya Tuhan berdasarkan dua macam gerakan yang ada di dunia ini, yakni gerakan asli dan gerakan yang digerakkan. Gerakan asli hanya bisa dilakukan oleh wujud yang hidup, sedangkan gerakan yang digerakkan tergantung pada gerakan dari wujud yang hidup. Plato menyatakan bahwa seluruh gerak alam semesta ini secara mutlak disebabkan oleh aktivitas sesuatu yang berjiwa. Dan wujud inilah yang mengatur dan memelihara sehingga disebut sebagai Yang Maha Pemelihara dan bersifat Maha Bijaksana.

Gagasan Plato tersebut diikuti oleh muridnya yakni Aristoteles pada tahun 384-322 SM. Aristoteles meneruskan gagasan tentang dua macam gerak milik Plato sebelumnya. Aristoteles memandang setiap benda yang dapat ditangkap oleh panca indera mempunyai materi (matter) dan bentuk (form) yang terdapat di dalam tiap-tiap benda itu sendiri, bukan di luar benda sebagaimana ide Plato. Bentuk tersebut yang membuat materi dan memiliki bangunan atau rupa. Tapi, bentuk ini tak dapat berdiri sendiri terlepas dari materi yang ia miliki di dalamnya. Hakikatnya materi dan bentuk selamanya satu. Materi tanpa bentuk tidak ada dan keduanya hanya dapat dipisahkan di dalam akal, tetapi dalam kenyataannya mereka merupakan kesatuan.

Selanjutnya adalah Antony Flew yang telah meyakini tentang keberadaan Tuhan setelah dirinya tidak lagi ateis dan memutuskan menjadi orang yang percaya terhadap adanya Tuhan. Flew meyakini eksitensi Tuhan didasarkan pada gagasan Tuhan dari Aristoteles yakni eksistensi yang tidak memiliki keterhubungan dengan kebiasaan hidup manusia. Flew juga menggambarkan pandangan maupun kepercayaan Aristoteles terhadap Tuhan yang bersifat transendensi dari manusia adalah sesuatu yang memiliki kekuatan dan 
kecerdasan yang lebih besar daripada dalam berbagai konsep kepercayaan ilahi di berbagai agama. Konsep Deisme adalah yang menjadi identitas Antony Flew dalam kepercayaannya terhadap eksistensi Tuhan.

Antony Flew hanya meyakini eksitensi Tuhan yang didasarkan secara saintifik. Flew tidak pernah tertarik dengan argumentasi kosmologi yang berasal dari berbagai agama karena menurutnya tidak memiliki pendasaran yang kuat dalam membuktikan eksistensi Tuhan selain berdasar pada pembuktian ilmiah, yang ia sebut dengan Intelligent Design. Gagasan ini dibangun dalam 2 (dua) alasan: (1) mengenai asal-usul hukum alam, beserta hubungannya dengan berbagai pandangan terkemuka para saintis modern melalui berbagai pembuktiannya pula dan (2) tentang asal-usul kehidupan dan reproduksi dalam makhluk hidup.

Menurut Aristoteles, pembuktian ini di dasarkan atas keharusan adanya causa efficiens, artinya suatu causa (sebab) yang menjadi asal mula perubahan. Pembuktian Aristoteles ini dinyatakan dengan jelas di dalam karya metafisika dan dihubungkan dengan pembuktian tentang adanya penggerak yang tidak bergerak (atau penggerak pertama) (Kattsoff, 2014: 443). Dengan mudah dipahami, segala sesuatu menjadi ada, mempunyai sebab. Kiranya sebab-akibat berlaku dimana-mana. Sebagai akibatnya ialah, apa yang sekarang ada dan yang sebelumnya tidak ada, tentu mempunyai sesuatu sebab, yang dirinya sendiri tentu juga mempunyai suatu sebba, dan begitulah seterusnya. Apabila rangkaian sebab-akibat ini berlangsung terus menerus tidak terhingga, setiap sebab juga akan menjadi suatu akibat dan dengan demikian berarti tidak ada sebab. Jika demikian, keadaan yang ada dewasa ini tidak dapat dijelaskan dan diliputi oleh tabir rahasia. Karena itu, sudah tentu ada suatu sebab pertama, yang dirinya sendiri tidak disebabkan oleh sesuatu yang lain. Sebab pertama terjadinya perubahan di alam semesta inilah yang disebut sebagai Tuhan.

\subsection{Argumen Desain tentang Eksistensi Tuhan}

Argumen desain diasumsikan dengan apabila semesta adalah sebuah tatanan yang teratur, maka terdapat rancangan atas tatanan tersebut dan rancangan mensyaratkan perancang, sehingga perancang itu ada maka dalam konteks ini Tuhan sebagai perancang sebuah tatanan semesta yang amat teratur tersebut. Antony Flew berpendapat, hukum alam merupakan suatu pengaturan yang "menundukkan" berbagai peristiwa fisik di alam untuk membentuk suatu simetri atau keselarasan penataan. Gagasan ini dapat dibuktikan beberapa di antaranya seperti: (1) Hukum Boyle mengatakan jika suatu temperatur konstan, maka akan menghasilkan jumlah produksi suatu volume dan tekanan suatu gas yang juga konstan; (2) Hukum I Newton mengenai kelembaman, berkata bahwa jika suatu obyek berada dalam kondisi diam, maka senantiasa dirinya berada dalam kondisi diam sekalipun mendapat perlakuan eksternal yang mengganggu ketidakstabilan eksistensinya; (3) Hukum Kekekalan Energi, juga berkata bahwa dalam kondisi yang konstan, maka total energi juga tidak mengalami perubahan.

Fakta berbagai hukum alam ini, tidak dapat dilepaskan dengan fakta bahwa alam semesta berangkat dari teori ledakan besar (big bang). Flew berpendapat bahwa sekalipun alam semesta tidak memiliki awal kemunculan 
eksistensi dan akhir kehancurannya, ketika dirinya masih ateis, hal ini menjadi fakta yang tidak ada hubungannya dengan fakta fenomena yang dapat diamati saat itu sebagai pemandangan bruto. Namun, hal ini terbantahkan dengan fakta big bang sendiri, dan berakhir pada pertanyaan tentang apa dan bagaimana tentang faktor maupun proses yang membuat alam semesta ini eksis, sampai pada keteraturan pascaledakan besar terjadi hingga sekarang.

Hal penting dalam sekilas contoh mengenai adanya hukum alam dan keteraturan big bang tersebut, tidak hanya menunjukkan "pengaturan alam" semata di bawah suatu aturan, tetapi juga memiliki makna lain bahwa pengaturan tersebut bersifat presisi secara matematis, universal, dan teruntai satu-sama lainnya, membentuk suatu rangkaian makro yang terhubung, yang memberikan suatu pertanyaan dan jawaban pasti kepada para ilmuwan dari Sir Isaac Newton (1643-1727), Albert Einstein (1879-1955), hingga Heisenberg (19011976). Jawaban mereka sama, bahwa ini terbentuk karena "Pikiran Tuhan" hingga membentuk suatu penataan alam. Pemikiran semacam ini, tidak hanya ditemukan pada pemikiran para tokoh ilmuwan pada era pra-modern seperti Newton dan James Maxwell, namun para ilmuwan di era modern berikutnya juga menyebutkan bahwa berbagai hukum di alam adalah sebagai hasil dari pikiran Tuhan. Sebagaimana Hawking juga berpendapat bahwa semakin dalam seseorang memahami dan meneliti tentang alam semesta, maka semakin akan ditemukan bahwa di dalamnya terbangun atas hukum-hukum yang rasional. Dan oleh karena itulah alam semesta memiliki eksistensi sebagai hasil dari bagaimana seseorang mampu menjelaskan Tuhan sebagai jawaban aktor design.

Antony Flew juga menambahkan bahwa banyak berbagai studi tentang asal-usul kehidupan yang dilakukan oleh para ilmuwan, jarang menyentuh aspek filosofis mengenai temuan mereka tentang DNA, yang hanya terbatas pada penemuan fisik. Hal ini tentunya mengundang pertanyaan besar pada bidang filsafat berkenaan dengan DNA maupun RNA, yakni bagaimana bisa suatu alam semesta yang tidak memiliki wujud berpikir, namun mampu memproduksi suatu wujud dengan tujuan intrinsik, berbagai kemampuan dalam mereplikasi diri, juga dilengkapi dengan kode-kode kimia yang saling berpasangan satu sama lainnya. Kehadiran kompleksitas DNA ini, tentunya tidak memungkinkan terjadi tanpa "kecerdasan" (Flew dan Varghese, 2007: 123).

\subsection{Argumen Moral tentang Eksistensi Tuhan}

Seorang filsuf Immanuel Kant melakukan studi tentang bukti adanya Tuhan melalui metafisika moral. Kant menyebut filsafatnya sebagai filsafat transendental. Atas dasar epistemologi yang dikembangkan Immanuel Kant sehingga persoalan-persoalan seperti Tuhan, jiwa dan manusia sebagai ide-ide transendental. Immanuel Kant juga merupakan tokoh yang berupaya mengajukan bukti adanya Tuhan secara sistematis berdasarkan argumenargumen metafisika moral (Siwanto, 1998: 61).

Para filsuf dan teolog telah berusaha memperoleh gagasan tradisional tentang Tuhan. Tetapi berbeda pandangan dengan dunia modern ketika membahas konsep Tuhan karena ilmu pengetahuan dan agama merupakan suatu kajian yang otonom, dua-duanya tidak perlu menentukan konsep 
modifikasi demi bidang lain. Oleh karena itu, gagasan tentang eksistensi Tuhan agar dilindungi oleh modernitas yang korosif. Salah satunya dalam menggunakan pendekatan ini Immanuel Kant telah membedakan dua fungsi pikiran manusia yang sangat mendasar, yaitu ilmiah (teoretis) dan etis (praktis). Fungsi ilmiah yang dimaksud adalah pikiran manusia melihat dunia sebagai sesuatu yang tidak memiliki kebebasan dan tidak memiliki Tuhan. Fungsi secara praktis yang dimaksud adalah pikiran manusia perlu mensyaratkan keabadian dan itu berarti Tuhan. Immanuel Kant berusaha menjawab pandangan gandanya terhadap kenyataan yang tidak bertentangan dengan dirinya menggunakan teori persepsi dan kognisi. Menurut pandangan Immanuel Kant, pandangan ilmiah hanya memberikan penampakan, sedangkan pendekatan praktis mendekatkan pada persoalan realitas (Griffin, 2005: 89).

Sistem argumen yang diambil oleh Immanuel Kant, bahwa moral diambil tempat yang agak besar karena dia berkeyakinan teoretis bertolak dari dunia. Manusia meletakkan ide secara mutlak sehingga menyatakan diri sebagai hukum moral dari hidup. Manusia menyadari bahwa sesuatu yang baik itu tidak mungkin tercapai olehnya lewat tenaga sendiri, melainkan tidak ada jalan daripada percaya, dapat disimpulkan bahwa apabila tanpa diberikan bantuan bimbingan oleh seorang pengurus moral, manusia tidak akan tahu tujuannya. Teori Immanuel Kant imperatif kategoris (perintah yang berlaku secara mutlak) menurut Immanuel Kant adanya Tuhan merupakan hasil pemikiran yaitu tidak masuk akal adanya perintah moral, kalau tidak Tuhan yang mengatur perintah moral tersebut (Huijbers, 1995: 132).

\subsection{Argumen Teleologis tentang Eksistensi Tuhan}

Pembuktian keberadaan Tuhan dengan argumen teleologis menyatakan bahwa bukti akan segala keteraturan alam semesta memberikan kesimpulan akan keberadaan "Sang Perancang" yang tidak dapat disangkal. Segala keteraturan alam ini ada bukan karena sebuah kebetulan belaka, akan tetapi memiliki maksud dan tujuan-tujuan tertentu. Argumen ini berasal dari pengamatan atas keteraturan dan keterpaduan alam semesta ini melalui pengamatan, pengalaman dan berakhir pada suatu kesimpulan yang menyatakan bahwa hal-hal tersebut pastilah memiliki tujuan dan keterciptaannya haruslah merupakan karya dari seorang perancang tersebut harus bebas dari segala aturan yang mengikat, sehingga ia bebas berkreasi, dan zat yang bebas dari segala aturan yang mengikat itu adalah Tuhan.

Teleologi juga memandang bahwa segala sesuatu dipandang sebagai organisasi yang tersusun dari bagian-bagian yang memiliki hubungan saling terkait satu dengan yang lainnya serta saling bekerja sama. Tujuan dari semua adalah untuk kebaikan dunia dalam keseluruhan. Alam ini beredar dan bervolusi pada tujuan tertentu, yaitu apa yang disebut sebagai kebaikan universal, dan tentunya ada yang menggerakkan menuju ke tujuan tersebut dan membuat alam ini beredar maupun berevolusi kea rah tesebut. Dan inilah yang disebut sebagai Tuhan.

\section{PENUTUP}


Tuhan secara eksistensial tetap merupakan sesuatu yang supranatural atau berada di luar jangkauan pengetahuan manusia. Akan tetapi, relasi antara manusia dan Tuhan, alam dan Tuhan, memungkinkan Tuhan untuk didekati dan dipahami secara rasional. Filsafat ketuhanan mengajarkan manusia mengenai Tuhan melalui akal pikiran semata-mata yang kemudian kebenarannya didapat sesuai dengan wahyu (kitab suci), dan filsafat ketuhanan juga merupakan suatu pemahaman akal secara murni atas kebenaran dan konsep-konsep dan imajinasi yang sesungguhnya, tidak dapat dijangkau oleh cara pengungkapan konvensional. Manusia berusaha mencari-cari bukti terkait dengan adanya Tuhan. Dengan demikian bukti mengenai adanya Tuhan didasarkan pada argumen ontologis, argumen kosmologis, argumen desain, argumen moral dan argumen teleologis.

\section{DAFTAR PUSTAKA}

Apau, Micheal Barimah. 1989. The God of Plato in Dialogues. Pontificia Universitas Urbania, Roma.

Armstrong, Karen. 2021. Sejarah Tuhan. PT Mizan Pustaka. Bandung.

Bahrum. 2013. Ontologi, Epistemologi dan Aksiologi. Jurnal Sulesana. Vol. 8 No. 2.

Flew, Antony dan Roy Abraham Varhese. 2007. There is God. Harper Collins ebooks.

Griffin, David Ray. 2005. Tuhan dan Agama dalam Dunia Postmodern. Yogyakarta: Kanisius.

Huijbers, Theo. 1995. Mencari Allah Pengantar Kedalam Filsafat Ketuhanan. Yogyakarta: Kanisius.

Kattsoff, Louis O. 2004. Pengantar Filsafat. Diterjemahkan oleh Soejono Soemargono. Yogyakarta: Tiara Wacana.

Makhuroh, Lailatul. 2017. Pembuktian Realitas Tuhan Melalui IQM (Intellectual Quality Management). Surabaya: Proceeding Ancoms.

Magnis Suseno, Frans. 2006. Menalar Tuhan. Kanisius. Yogyakarta.

Mustofa, Agus. 2008. Membonsai Islam. Surabaya: Padma Press.

Siswanto, Joko. 1998. Sistem-sistem Metafisika Barat dari Aristoteles Sampai Derrida. Yogyakarta: Pustaka Pelajar.

Wibowo. 2006. Sesudah Filsafat. Yogyakarta: Kanisus.

Weisman, Ivan Th J. 2005. Filsafat Ketuhanan Menurut Plato. Jurnal Jaffray. 